\title{
VOORWOORD VAN DIE REDAKSIE
}

Op die eerste April van hierdie jaar was dit vyf-en-twintig jaar gelede dat die jeugdige, toe 29-jarige dr. S. P. Engelbrecht sy akademiese werksaamhede aan die destydse Transvaalse Universiteitskollege, later uitgegroei tot die Universiteit van Pretoria, begin het. Op daardie dag het sy kollegas en sy studente in die Nederduitsch Hervormde Kerk se Afdeling van die Teologiese Fakulteit in geslote kring hulle dankbaarheid aan die jubilaris kenbaar gemaak. 'n Vetslag van hierdie vertigting kan gevind word in „Die Volkstem" van 2 April 1946.

Die Hervormde Kerk, die Universiteit en sy vele vriende het daarna op die 29ste Mei, die dag waarop dr. Engelbrecht in 1921 tot Bedienaar van die Woord georden is, in 'n groot samekoms in die Stadsaal van Pretoria sy werk vir Kerk, Universiteit en samelewing gehuldig. 'n Uitvoerige verslag daarvan asook van die gedagtenisrede deur die jubilaris in die aand in die kerkgebou van die Nederduitsch Hervormde Gemeente van Pretoria gehou, het in die „Die Hervormer” van 20 Julie 1946 verskyn.

Die Redaksie van die Hervormde Teologiese Studies (hierdie keer buite sy volywerige sekretaris om) het gemeen nie te mag agterweë bly nie in die dankbare erkenning van die verdienstes van Professor Engelbrecht vir die wetenskaplike Teologie, vir die beoefening waarvan hy mede deur die oprigting van hierdie Studies so geesdriftig en volhardend meegewerk het. Die inisiatief tot hierdie tydskrif het allereers en vernaamlik van hom uitgegaan, die verkry van baie intekenaars en belangstellende lesers was grotendeels sy werk en behalwe deur gereelde waardevolle bydraes van sy hand op die terreine van sy studie, het hy as sekretaris van die Redaksie steeds 'n groot andeel gehad in die versorging van die uitgawe.

Die plan van die Redaksie om die laaste twee aflewerings van hierdie derde jaargang in 'n dubbelnummer saam te vat en dit aan Professor Engelbrecht op te dra, het uit die staanspoor hartlike instemming en medewerking gevind by die Uitgewer in die persoon van die heer $\mathrm{L}$. L. Steen, wat 'n besondere versorging van die uitgawe toegesê het. Ewe spontaan was die medewerking van kollegas-professore op allerlei terreine van die geesteswetenskappe, oudleerlinge en vriende wat hulle bydraes, twee oor die persoon en werk van die jubilaris en verder elkeen op hulle besondere studieterrein, blykbaar met graagte ingestuur het.

Ons ag dit 'n voorreg dat ons ook drie teologiese hooglerare van Nederlandse Unive1 siteite onder die bydraers mag reken, onder wie ook die 77-jarige oud-leermeester van prof. Engelbrecht, professor dr. H. Th. Obbink. Hulle, die verstes, was die eerstes om aan die oproep van die 
Redaksie gehoor te gee. Een van hulle het geskryf: „Ik ben erg blij mee te kunnen werken aan de zoo welverdiende huldiging van Engelbrecht, en zou dit uit persoonlijke neiging reeds gaarne doen, ook al waren zijn verdiensten niet zoo groot en zijn aanspraak op onze dankbaarheid niet van dien aard als gij ook weer schrijft." Soos uit hulle briewe blyk, is vriendskap en waardering vir professor Engelbrecht vriendskap en waardering vir Suid-Afrika.

Mag dit aan professor Engelbrecht gegee word om nog vele jare sy gawes en kragte te wy aan Teologie en Kerk, geskiedvorsing en volkseie. Met hom gedink ons Gods goedertierenheid binne-in Sy tempel.

B. Gemser, Voorsitter.

A. S. GeYser, Penningmeester. 